læser, der søger overblikket, kunne have ønsket sig en efterstillet bibliografi til hver introducerende tekst, der oplistede de 5-10 vigtigste værker inden for området - især da, når nu værket ledsages af to bind, det ene på knap 1000 sider, det andet 650, som grundigt kommenterer kildegrundlaget, de tekstkritiske varianter og receptionen af de enkelte tekster i Konkordieværket. Disse to bind er uundværlige for den, der arbejder med aspekter af ikke blot den begyndende lutherske ortodoksis kirkehistorie, men også for den, der beskæftiger sig med dogmeudviklingens historie. For den, der ikke har disse interesser, kan tekstbindet for en lavere pris købes separat.

Realkommenteringen af de enkelte tekster i Konkordieværket udgør en guldgrube af oplysninger, som denne anmelder ikke ville have været foruden. Kommenteringen er inddelt i tre: tekstkritik, receptionshistorie og indholdskritik. Her er henvisninger til tekstvarianter, bibelsteder, årstal, personer, væsentlige intertekstuelle referencer, kanonisk ret, kirkelig praksis osv. Alt sammen opdateret til den nuværende forskningssituation. Det er centralt for det videnskabelige arbejde med teksten og beviser en nyudgivelse af Konkordieværkets nødvendighed.

Det verserende reformationsjubilæum afstedkommer et væld af udgivelser $\mathrm{i}$ ind- og udland. Mange af dem brændes på erindringens alter. Die Bekenntnisschriften der Evangelisch-Lutherischen Kirche bør det ikke gå sådan.

Mattias Skat Sommer

\title{
Risto Saarinen
}

Recognition and Religion. A Historical and Systematic Study. Oxford: Oxford University Press 2016. 268 s. \$ 80.00.

De seneste årtier har psykologisk og socialfilosofisk forskning interesseret sig for at afdække, i hvilken forstand sociale relationer beror på et universelt menneskeligt behov for anerkendelse. Med sin bog om anerkendelse og religion vil Risto Saarinen udforske anerkendelsens systematisk-teologiske potentiale med baggrund i en undersøgelse af det kristne anerkendelsesbegreb, sådan som det udvikler sig fra nytestamentlig tid og til i dag. Dermed vil Saarinen udfordre den socialfilosofiske forståelse af anerkendelse som et moderne, sekulært begreb med rødder i Hegels filosofi. Undersøgelsen tager sit udgangspunkt i en minimumsbestemmelse af religiøs anerkendelse som en godkendelseshandling, der indebærer kognitiv identifikation, social tilknytning samt en given relation mellem en anerkendende part, oftest mennesket, og en anerkendt part, oftest Gud. Ifølge Saarinen opstår der allerede i den tidlige kristendom en relativ stabil terminologi til betegnelse af menneskets anerkendelse af Gud med centrum i ordene agnosco og recognosco.

Saarinens undersøgelse spænder vidt. I den introducerende del 1 skitseres den filosofiske anerkendelsesdiskurs hos blandt andre frankfurtersociologen Axel Honneth og filosoffen Charles Taylor samt hos de franske fænomenolo- 
ger Marcel Hénaff og Paul Ricœur, der forbinder anerkendelsesbegrebet med undersøgelsen af gavegivning som grundfænomen ved menneskelig socialitet. Saarinen berører desuden den spirende interesse for anerkendelse inden for nutidig systematisk teologi hos for eksempel Jan-Olav Henriksen og Veronika Hoffmann. I del 2 og 3 udfolder Saarinen sin begrebshistoriske analyse af anerkendelsens rolle i vestlig teologi. Del 2 begynder i Det Nye Testamente og når forbi blandt andre Augustin, Thomas Aquinas og Bernhard af Clairvaux for til sidst at berøre Martin Luther og Jean Calvin. Del 3 tager udgangspunkt i den politiske filosofi hos Thomas Hobbes og når via pietisme, tysk idealisme og Schleiermachers dogmatik frem til kulturprotestantisme og dialektisk teologi for at ende ved FN's menneskerettighedserklæring. Desuden diskuterer Saarinen anerkendelsesbegrebets rolle i økumeniske debatter samt dets potentiale i forhold til spørgsmål om interkulturel sameksistens.

I bogens afsluttende del 4 drager Saarinen de systematisk-teologiske konsekvenser af sin begrebshistoriske analyse ved at sammenfatte tre paradigmer for religiøs anerkendelse, der udvikler sig gennem historien. Som det første paradigme fremhæver Saarinen omvendelseshistorierne i fx Det Nye Testamente og hos Augustin, hvori det beskrives, hvordan mennesket på baggrund af sin anerkendelse af Gud oplever en af Gud forårsaget omvendelse, der grundlæggende ændrer dets identitet. Til forskel herfra udfoldes i middelalderen og den tidlig moderne periode hos blandt andre Luther og Calvin et anerkendelsesparadigme, som understreger, at menneskets anerkendelse af Gud er gensidigt forbundet med Guds løfte om frelse, der indebærer en genoprettelse af menneskets sande identitet. Hvor både det første og det andet paradigme fremhæver menneskets opadgående anerkendelse af Gud, betoner det tredje paradigme, som først og fremmest udfoldes i Schleiermachers Glaubenslehre, mennesket som den af Gud anerkendte part, der erfarer en statusændring.

Bogens spændvidde cementerer anerkendelse som et begreb med afg $\varnothing$ rende betydning for fremstillingen af forholdet mellem Gud og menneske gennem teologihistorien. Særligt interessant fra et systematisk teologisk perspektiv er Saarinens tese om, at luthersk retfærdiggørelseslære udgør et intuitivt modstykke til moderne socialpsykologiske eller -filosofiske anerkendelsesteorier, idet begge kredser om den statusændring, som anerkendelsen medfører. Analogien har dog sin begrænsning deri, at den samfundsmæssige anerkendelse ikke inkluderer en forestilling om synd. Saarinen fremhæver Eberhard Jüngel som en nutidig teolog, der benytter anerkendelse som et genuint teologisk begreb i sin fortolkning af retfærdiggørelseslæren, men påpeger samtidigt og med rette, at begrebet benyttes relativt ureflekteret $\mathrm{og}$ generelt endnu lever en skyggeeksistens i moderne teologi.

I kombination med det knappe format bevirker bogens spændvidde desværre, at de enkelte analyser på trods af en række spændende pointer fremstår kursoriske og indforståede, samt at valget af forfattere og tekster får et præg af tilfældighed over sig. Det gælder for eksempel afsnittet om Luther, 
der hævder, at Luther benytter verbet agnosco til at beskrive menneskets anerkendelse af Gud gennem syndsbekendelse, men som ikke har blik for de mange relaterede verber, hvormed Luther udtrykker denne anerkendelseseller måske snarere æresrelation ( $\mathrm{fx}$ glorifico, honoro, colo). For at tydeliggøre bogens anliggende kunne de anerkendelsesparadigmer, som Saarinen konkluderende opregner, være benyttet som rettesnor for den historiske analyse. Dermed ville Saarinens systematisk-teologiske udfoldelse af det bidrag, som den religiøse anerkendelsestradition bibringer forståelsen af menneskets universelle anerkendelsesbehov, være trådt tydeligere frem.

Sasja Emilie Mathiasen Stopa 